\title{
FIRM SIZE AND ECONOMIC DEVELOPMENT: EVIDENCE FOR THE BRAZILIAN MUNICIPALITIES'
}

\author{
Douglas Mesquita Carneiro² \\ Carlos Eduardo Lobo e Silva ${ }^{3}$ \\ Geoffrey J. D. Hewings ${ }^{4}$
}

This work uses spatial econometric analysis to investigate the importance of the size of firms for the economic development indicators of the Brazilian municipalities from 2000 to 2010. The investigation is motivated by the amount of resources and effort that governments dedicate to policies attracting and supporting local business. The estimated models present dissimilarity findings across sectors and development indicators. For instance, the sign of the relationship between employment growth and the size of firm depends on the sectors considered. Thus, the results recommend special attention on the part of policy makers in formulating their local development strategies.

Keywords: firm size; economic development; spatial econometric.

\section{TAMANHO DAS EMPRESAS E DESENVOLVIMENTO ECONÔMICO: EVIDÊNCIAS PARA OS MUNICÍPIOS BRASILEIROS}

0 trabalho utiliza análises econométricas espaciais para investigar a importância do tamanho das empresas para os indicadores de desenvolvimento econômico dos municípios brasileiros de 2000 a 2010. A investigação é motivada pela quantidade de recursos e esforços que os governos dedicam às políticas que atraem e apoiam negócios locais. Os modelos estimados apontam diferentes resultados entre setores e indicadores de desenvolvimento. Por exemplo, o sinal da relação entre o crescimento do emprego e o tamanho da empresa depende dos setores considerados. Assim, os resultados recomendam atenção especial aos formuladores de políticas na elaboração de suas estratégias de desenvolvimento local.

Palavras-chave: tamanho das empresas; desenvolvimento econômico; econometria espacial.

\section{TAMAÑO DE LAS EMPRESAS Y DESARROLLO ECONÓMICO: EVIDENCIA PARA LOS MUNICIPIOS BRASILEÑOS}

El trabajo utiliza análisis econométrico espacial para investigar la importancia del tamaño de las empresas para los indicadores de desarrollo económico de los municipios brasileños de 2000 a 2010. La investigación está motivada por la cantidad de recursos y esfuerzos que los gobiernos dedican a las políticas de atracción y apoyo a las empresas locales. Los modelos estimados muestran resultados diferentes entre sectores e indicadores de desarrollo. Por ejemplo, el signo de la relación entre el crecimiento del empleo y el tamaño de la empresa depende de los sectores considerados. Por lo tanto, los resultados recomiendan una atención especial por parte de los formuladores de políticas en la formulación de sus estrategias de desarrollo local.

Palabras clave: tamaño de las empresas; desarrollo económico; econometría espacial.

1. DOI: http://dx.doi.org/10.38116/ppp54art04

2. Professor at the Lutheran University of Brazil (Ulbra) - Campus Torres. E-mail: <douglasmcarneiro@hotmail.com>.

3. Professor at the Pontifical Catholic University of Rio Grande do Sul (PUCRS). E-mail: <carlos.silva@pucrs.br>.

4. Emeritus professor at the University of Illinois at Urbana-Champaign. E-mail: <hewings@illinois.edu>. 


\section{TAILLE DES ENTREPRISES ET DÉVELOPPEMENT ÉCONOMIQUE: DONNÉES PROBANTES POUR LES MUNICIPALITÉS BRÉSILIENNES}

Le document utilise des analyses économétriques spatiales pour étudier l'importance de la taille des entreprises pour les indicateurs de développement économique des municipalités brésiliennes de 2000 à 2010. La recherche est motivée par la quantité de ressources et d'efforts que les gouvernements consacrent aux politiques qui attirent et soutiennent les entreprises locales . Les modèles estimés montrent des résultats différents entre les secteurs et les indicateurs de développement. Par exemple, le signe de la relation entre la croissance de l'emploi et la taille de l'entreprise dépend des secteurs considérés. Les résultats recommandent donc une attention particulière aux décideurs dans l'élaboration de leurs stratégies de développement local.

Mots-clés: taille des entreprises; développement économique; économétrie spatiale.

JEL: C31; L11;010; R11.

\section{INTRODUCTION}

Firm size has been object of intense investigation in economic literature. Normally the focus of this research object is the contrast between large business - the major players in the market - and a great number of small enterprises, that are individually vulnerable and sometimes dependents of public support, but collectively endowed with vast political capital (Moscarini and Postel-Vinay, 2012). However, empirical evidence is rather mixed about whether small and large firms differ in the aggregate, in terms of their impact on overall economic growth (Bruce et al., 2009).

According to Shaffer (2006a) if the firm size is important, there could be some characteristics associated to the large firms that might stimulate growth, and perhaps other factors related to the small firms that can act in favor of growth. A better understanding about these possibilities can stimulate the growth and development of a region or county.

Part of the debate in the literature is related to which created more jobs, the small business or the large ones. In favor of small firms, some research has shown the small firms as the greatest contributors to the employment growth (Komarek and Loveridge, 2015; Neumark, Wall and Zhang, 2011; Shaffer, 2006a).

Deller and McConnon Junior (2009), in their analysis for the U.S. states, suggest that the relation between employment growth and microenterprises change according to the sector. A higher share of microenterprises in the producing sector is associated with higher levels of employment growth. In the service sector, these enterprises have a positive relationship with the growth of employment.

In contrast to the works presented above, Bruce et al. (2009) and Ayyagari, Demirguc-Kunt and Maksimovic (2014) found a positive relation between large firms and employment growth. Indicating that faster employment growth is found in places with more large-firm activity. 
The debate is also addressed in the relation between per capita income and firm size, more specifically an important trend in economic development policy-making is the promotion of small firms to enhance local economic growth.

However, as in the firm size-employment relation, with the results found in the literature is not possible asserting precisely which size firms are more significant contributors to the per capita income growth, depending mostly on the level of local development. Deller (2010) points out that in developing regions where institutions are not well established, the role of small business is unclear. Thus, in developing countries the relation between small firms and income growth may be negative (Acs, Desai and Hessels, 2008; Deller, 2010; Van Stel, Carree and Thurik, 2005).

In a context of developed economies, the findings indicate that smaller firms are associated with faster growth of income (Deller and McConnon Junior, 2009; Shaffer, 2002; Shaffer, 2006b). Komarek and Loveridge (2015), in turn, show that the most important for the regional income growth are the medium sized firms.

Firm size distribution can also be important to reduce poverty. Even though this concept is not well addressed in the literature there are some studies analyzing three factors associated to firm size and poverty reduction: these factors are, small and medium enterprise sectors (SME), entrepreneurship and self-employment.

As noticed by Deller and McConnon Junior (2009) most of the staff employed in small businesses is derived from secondary labor markets (e.g. lower education levels, women, minorities, immigrants, etc.). Thereby the promotion of small business may represent a poverty mitigation strategy (Deller and McConnon Junior, 2009).

The importance of small enterprises for the poverty reduction is also defended by Gebremariam, Gebremedhin and Jackson (2004). According to the authors, by creating jobs and promoting economic growth, small businesses play a critical role in poverty alleviation. They also play an important role in community development by enticing private investment back into undeveloped areas and spreading the benefits of economic growth to people and places too often left behind.

Another significant way to alleviate poverty is related to entrepreneurship. However, there are a reduced number of researches focusing in the relation between entrepreneurship and poverty, especially in developing countries. Amorós and Cristi (2011) found results indicating that entrepreneurship activities have a positive effect in reducing poverty.

In developing countries, the entrepreneurs are self-employed or have only a reduced number of employees (Banerjee and Duflo, 2007). Then, as well as entrepreneurship and SME, the self-employment could be a way to reduce poverty. 
Rupasingha and Goetz (2013) analyzed the relation between poverty and self-employment, providing empirical evidence of the support of self-employment as a way to reduce the countrywide poverty.

As can be noted in the international academic literature, the firm size is a relevant issue and can be considered one of the relevant factors for the growth and development of a region. However, this issue is still little discussed in Brazil. In this sense Cravo, Becker and Gourlay $(2012 ; 2015)$ investigate exclusively the relation between small and medium-sized enterprises (SME) and economic growth in Brazilian micro regions. The authors have found evidence suggesting a negative relation between SMEs and growth. However, when included the human capital variable in the small and medium size business variable, the relation becomes positive.

Before the analysis so far, this work aims in addition to filling a gap in Brazilian academic literature, to analyze more thoroughly the relationship between size of business and economic development. Therefore, the proposed models enable - in contrast with other articles on the subject for Brazilian economy - to estimate the relation between the firm size and income, employment and poverty growth in different sectors of the 5507 Brazilian municipalities from 2000 to 2010.

The relation between the size firms and economic growth is analyzed, considering the presence of geographic spillovers, as failing to consider aspects such as spatial dependency may cause econometric problems as omitted variable bias and endogeneity (Badinger, Müller and Tondl, 2004; Ertur and Koch, 2007; Mohl and Hagen, 2010).

In addition to this introduction, the article is divided into three more sections. In section 2, the methodologies and data used in this study are described. Section 3 presents an exploratory analysis of data and presents the main findings of the work. Next, final comments close the article.

\section{METHODOLOGICAL ASPECTS}

\subsection{Specification of models}

The empirical strategy of analyzing the relation between establishment size and economic growth of municipalities is set by using economic growth equations, according to the proposal of Beck, Demirguc-Kunt and Levine (2005), Bruce et al. (2009) and Shaffer (2002; 2006b).

Therefore, the hypothesis to be tested may be described through the following equation:

$$
\text { Growth }_{i}=\alpha+\beta \text { FirmSize }_{i}+\delta \text { ConditionalSet }_{i}+\rho_{t}
$$


where $\operatorname{Growth}_{i}$ is the growth rate of per capita income, employment or poverty, $\beta$ FirmSize $_{i}$ refers to different size of enterprises, ConditionalSet ${ }_{i}$ is a standard variable vector used in economic growth equations, in this case referring to the log of income or employment in the initial year, human capital, physical capital, population density and population in the initial year, $\rho_{t}$ is an error term.

The presence of geographic spillovers in the economic growth of regions is considered, therefore econometric problems may occur (Badinger, Müller and Tondl, 2004; Ertur and Koch, 2007; Mohl and Hagen, 2010). According to Dall'erba and Le Gallo (2008) there are three reasons to incorporate spatial effects in growth models. First, from an econometric standpoint, one of the hypotheses of OLS estimations is based on the independence of error terms, and any violation of this assumption leads to unreliable estimates and inferences. Second, it enables to capture effects of geographic overflows between regions. Third, spatial discrepancies on the dependent variable can act as outdated dependent variables to explain omitted variables.

The Lagrangian Multiplier tests (Anselin, 1996) were used to choose between spatial models. The results indicated that in order to control the effects of spatial dependence, the most appropriate for income and employment models are the spatial error model (SEM). Nevertheless, for poverty model, the test indicates the spatial autoregressive model (SAR).

The SEM (spatial error model) models spatial dependence by the error term, and it can be described by the following equation:

$$
\begin{aligned}
& \text { Growt }_{i}=\alpha+\beta \text { FirmSize }_{i}+\delta \text { ConditionalSet }_{i}+\delta_{i} \\
& \delta_{i}=\theta \sum_{j=1}^{N} w_{i j} \delta_{j}+\varepsilon_{i}
\end{aligned}
$$

where variables are the same used in equation (1), except for the error term $\delta_{i}$, whi$\mathrm{ch}$, through the $w_{i j}$ term contains information regarding spatial structure and connectivity between regions $i \mathrm{e} j, \theta$ is the spatial error coefficient and $\varepsilon \sim N\left(0, \sigma^{2}, I_{n}\right)$. This specification indicates that a random shock introduced in a region affects all regions through the spatial structure.

In the SAR (spatial autoregressive model), the spatial dependence is included in the model through the spatially lagged values of the dependent variable, as described in equation (3).

$$
\text { Growth }_{i}=\rho \sum_{j=1}^{N} w_{i j} \text { yrowth }_{j}+\beta \text { ZFirmSize }_{i}+\text { ConditionalSet }_{i}+\rho_{i t}
$$


where $\rho$ is the spatial autoregressive parameter and the other variables are the same used in the equation (1).

We use four different measures for establishment size, then the equation (2) is estimated using a single measure of establishment for each sector and each dependent variable, resulting in twelve separates sets of estimates for each dependent variables.

\subsection{Exploratory spatial data analysis}

The presence of spatial dependence will be tested through exploratory spatial data analysis (ESDA), showing if the parameters used in the analysis are constant or not in space.

The Moran's I test measures the level of global spatial autocorrelation, and is written in the following form:

$$
I_{t}=\left(\frac{n}{s_{0}}\right) \frac{\sum_{i=1}^{n} \sum_{j=1}^{n} w_{i j}\left(y_{i}-\bar{y}\right)\left(y_{j}-\bar{y}\right)}{\sum_{i=1}^{n}\left(y_{i}-\bar{y}\right)^{2}}
$$

where $w_{i j}$ is a binary element of spatial weight matrix $W$ which assumes value equal to 1 if the regions $i$ e $j$ are spatially connected, otherwise the value of the $w_{i j}$ is zero; $y_{i}$ denotes the analyzed variable in region $i, y$ is the average value of the variable; $n$ is the number of regions; e $S_{0}$ is the sum of all elements of $W$.

Values of $I_{t}$ higher (smaller) than the expected value $E(I)=-\frac{1}{n-1}$ indicates positive (negative) spatial autocorrelation.

\subsection{Data specification}

The object of the analysis of this study is comprised of the 5507 municipalities in Brazil. In order to achieve the goals initially proposed, we used information deriving from different statistical basis regarding the period from 2000 to 2010 (table 1).

The dependent variables are the growth rates of per capita income, employment and poverty between the years 2000 and 2010. All explanatory variables are related to the first year of the analysis. This procedure aims to mitigate the endogeneity problem from the reverse causality (Bruce et al., 2009; Deller, 2010; Komarek and Loveridge, 2015; Shaffer, 2006a).

The variables related to human capital were divided into educational capital percentage of individuals aged 25 years or older that completed high school and health capital - infant mortality. It was decided to divide the human capital in educational capital and health capital, as in McDonald and Roberts (2002), because, according to the authors, not only the educational capital is positively 
related to economic growth, but also a healthier population tends to be more productive and hence generate more growth, moreover its omission can generate a bias in the model.

TABLE 1

\section{Variables and sources}

\begin{tabular}{lcl}
\hline Dependent variables & Year & Source \\
\hline Per capita GDP growth & $2000-2010$ & Ipeadata/IBGE \\
Employment growth & $2000-2010$ & Rais \\
Poverty growth & $2000-2010$ & Atlas do Desenvolvimento Humano \\
\hline Independent variables & & \\
\hline In per capita income & 2000 & Ipeadata/IBGE \\
In employment & 2000 & Atlas do Desenvolvimento Humano \\
In population & 2000 & Ipeadata/IBGE \\
Education & 2000 & Atlas do Desenvolvimento Humano \\
Child mortality & 2000 & Atlas do Desenvolvimento Humano \\
Physical capital & 2000 & Ipeadata/IBGE \\
Population density & 2000 & Ipeadata/IBGE \\
Microenterprise & 2000 & Rais \\
Small enterprise & 2000 & Rais \\
Medium enterprise & 2000 & Rais \\
Large enterprise & 2000 & Rais \\
\hline
\end{tabular}

Authors' elaboration.

The stock of residential capital was defined as a proxy for physical capital. This variable, is a component of overall physical capital stock (Chen, Guo and Zhu, 2011) and is used for analysis of smaller geographical units in Brazil (Barros Neto, Nakabashi and Sampaio, 2013; Lima and Silveira Neto, 2016; Nakabashi, Pereira and Sachsida, 2013).

The variable population density refers amount of individuals per square kilometer. It was inserted in the equation as a proxy for the agglomeration effects.

The firm size variable is gathered by calculating the ratio between the quantity of manufacturing (service) employees in each size and the quantity of employees in the total industrial (service) employment. Then, the firm size variable is measured by the share of the employment in four different categories of firm size in the total formal labor force in manufacturing and service sector, as in Beck, Demirguc-Kunt and Levine (2005) and Komarek and Loveridge (2015).

Table 2 shows the result of calculating the firm size variable to a random municipality. 
TABLE 2

Example

$(\ln \%)$

\begin{tabular}{|c|c|c|c|c|c|}
\hline Sector & Size & Microfirms & Small firms & Medium firms & Large firms \\
\hline Manufacturing & & 19.71 & 28.19 & 7.68 & 44.42 \\
\hline Service & & 18.05 & 20.82 & 9.31 & 51.82 \\
\hline
\end{tabular}

Sources: Rais (available at: <https://bit.ly/3bbz8Y2>; accessed on: Jan. 15, 2016); Sebrae (available at: <https://bit.ly/2DiBvMg>; accessed on: Oct. 20, 2015).

Authors' elaboration.

The definitions of size are based in Brazilian institutions (IBGE and Sebrae) in which the size of establishments are defined as the number of employees (table 3 ), and this definition is used by these institutions for policies in credit, technologies and export.

\section{TABLE 3}

Definition of firm size

\begin{tabular}{|c|c|c|c|c|c|}
\hline Sector & Size & Microfirms & Small firms & Medium firms & Large firms \\
\hline Manufacturing & & $<19$ employees & Between 20 and 99 & Between 100 and 499 & > 500 employees \\
\hline Service & & $<9$ employees & Between 10 and 49 & Between 50 and 99 & > 100 employees \\
\hline
\end{tabular}

Source: Sebrae. Available at: <https://bit.ly/2DiBvMg>. Accessed on: Oct. 20, 2015.

Authors' elaboration.

\subsection{Weight matrix}

In order to express spatial interactions between municipalities, it is necessary to specify how these areas comprising the sample are connected, and the tool used to represent this connectivity is the spatial weights matrix.

In a spatial weight matrix the neighbor structure is defined by a $n \times n$ positive matrix $(W)$ in which each element $w_{i j}$ of the $W$ matrix indicates how the localization $i$ and localization $j$ are spatially connected. The spatial weights $w_{i j}$ are nonzero if the localization $i$ and $j$ are physically adjacent, and zero otherwise.

The matrix choice is according the structure of the sample. Since the size of the municipalities is not homogeneous, the use of a weight matrix based on distance or contiguity is likely to lead to a very unbalanced connectedness structure. A common solution to this problem consists of considering nearest neighbors weight matrices, forcing each unit to have the same number of neighbors (Anselin, 2002; De Dominicis, Arbia and De Groot, 2013). 
The concept of the $k$ nearest neighbors is calculated from the distance between the centroids of the regions and the form of this matrix is the following:

$$
W=\left\{\begin{array}{c}
w_{i j}^{*}(k)=0 \text { if } i=j \\
w_{i j}^{*}(k)=1 \text { if } d_{i j} \leq d_{i}(k) \\
w_{i j}^{*}(k)=0 \text { if } d_{i j}>d_{i}(k)
\end{array}\right.
$$

where $d_{i}(k)$ is the critical cut-off distance for each region $i, d_{i j}$ is the great circle distance between centroids of region $i$ and $j$. This spatial structure means that each region has exactly $k$ neighbors.

In this study, the spatial weights matrices of the nearest $k$-neighbors $(k=5)$ will be used.

\section{FINDINGS}

In this section the findings obtained from the estimations of the employment, income and poverty growth models are reported. The models were estimated by spatial error model (SEM) - for income and employment - and by spatial autoregressive model (SAR) for poverty. The $k$-nearest matrix $(k=5)$ was used for estimate all models.

The spatial parameters $\lambda$ - spatial parameter for the spatially lagged error term - and $\rho$ - spatial autoregressive parameter for the spatially lagged dependent variable - presented positive and significant values in all estimations. This indicates that the spatial structure influences the path of the growth rate and that neglecting spatial dependence may generate omitted variable bias and lead to inconsistent estimators.

In income model (table 4), all the explanatory variables from income model presented statistical significance, indicating several consistent determinants of income growth. The negative sign of the natural logarithm of income in the initial year is in accordance with neoclassical growth models. Such finding indicates a convergence process, in which regions with lower levels of initial per capita income tend to grow more rapidly than those where this level of initial income is higher.

Same inverse relation was found to the variables health and population density, indicating that unhealthier population and agglomeration can lead to a lower income growth rate. The positive sign of the variables associated with human capital, physical capital also indicates the importance of these variables to the income growth of the municipalities. 
TABLE 4

Results of spatial error model (SEM) - income growth

\begin{tabular}{|c|c|c|c|c|c|c|c|c|}
\hline \multirow{4}{*}{$\begin{array}{l}\text { Variables } \\
\text { Ln income }\end{array}$} & \multicolumn{8}{|c|}{ Income growth } \\
\hline & \multicolumn{4}{|c|}{ Manufacturing } & \multicolumn{4}{|c|}{ Service } \\
\hline & $-0.5709^{* * *}$ & $-0.5738^{* * *}$ & $-0.5701 * * *$ & $-0.5703^{* * *}$ & $-0.5701^{* * *}$ & $-0.5702^{* * *}$ & $-0.5701 * * *$ & $-0.5702^{* * *}$ \\
\hline & $(-57.24)$ & $(-57.37)$ & $(-57.25)$ & $(-57.22)$ & $(-57.28)$ & $(-57.24)$ & $(-57.28)$ & $(-57.25)$ \\
\hline \multirow{2}{*}{ Ln population } & -0.0012 & -0.0025 & -0.0019 & -0.0014 & -0.0013 & -0.0017 & -0.0005 & -0.0016 \\
\hline & $(-0.51)$ & $(-0.9983)$ & $(-0.75)$ & $(-0.56)$ & $(-0.54)$ & $(-0.69)$ & $(-0.21)$ & $(-0.63)$ \\
\hline \multirow{2}{*}{ Education } & $0.0065^{* * *}$ & $0.0067^{* * *}$ & $0.0066^{* * *}$ & $0.0066^{* * *}$ & $0.0066^{* * *}$ & $0.0065^{* * *}$ & $0.0065^{* * *}$ & $0.0065^{* * *}$ \\
\hline & $(9.73)$ & $(9.97)$ & $(9.79)$ & $(9.79)$ & $(9.79)$ & (9.78) & $(9.78)$ & (9.79) \\
\hline \multirow{2}{*}{ Health } & $-0.0071^{* * *}$ & $-0.0070 * * *$ & $-0.0069 * * *$ & $-0.0071^{* * *}$ & $-0.0071^{* * *}$ & $-0.0071^{* * *}$ & $-0.0071^{* * *}$ & $-0.0071 * * *$ \\
\hline & $(-22.03)$ & $(-21.98)$ & $(-22.07)$ & $(-22.08)$ & $(-22.05)$ & $(-22.09)$ & $(-22.08)$ & $(-22.08)$ \\
\hline \multirow{2}{*}{$\begin{array}{l}\text { Population } \\
\text { density }\end{array}$} & $-0.000008^{*}$ & -0.000007 & -0.000008 & $-0.000008^{*}$ & $-0.000008^{*}$ & -0.00008 & $-0.000009^{*}$ & -0.00008 \\
\hline & $(-1.68)$ & $(-1.54)$ & $(-1.60)$ & $(-1.65)$ & $(-1.69)$ & $(-1.62)$ & $(-1.75)$ & $(-1.64)$ \\
\hline \multirow{2}{*}{ Physical capital } & $0.0373^{* * *}$ & $0.0370 * * *$ & $0.0367^{* * *}$ & $0.0369 * * *$ & $0.0370^{* * *}$ & $0.0368^{* * *}$ & $0.0370^{* * *}$ & $0.0369 * * *$ \\
\hline & (14.29) & $(14.25)$ & (14.11) & (14.17) & $(14.26)$ & (14.19) & $(14.26)$ & (14.20) \\
\hline \multirow{2}{*}{ Microfirms } & 0.0076 & & & & $-0.0236^{* * *}$ & & & \\
\hline & (1.63) & & & & $(-2.66)$ & & & \\
\hline \multirow{2}{*}{ Small firms } & & $0.0231^{* * *}$ & & & & 0.0082 & & \\
\hline & & (3.34) & & & & $(0.79)$ & & \\
\hline \multirow{2}{*}{ Medium firms } & & & 0.0070 & & & & $0.0165^{* *}$ & \\
\hline & & & $(0.78)$ & & & & (2.34) & \\
\hline \multirow{2}{*}{ Large firms } & & & & -0.0036 & & & & 0.0012 \\
\hline & & & & $(-0.27)$ & & & & $(0.21)$ \\
\hline \multirow{2}{*}{$\lambda$} & $0.5909^{* * *}$ & $0.5916 * * *$ & $0.5902^{* * *}$ & $0.5909^{* * *}$ & $0.5911^{\star * *}$ & $0.5901 * * *$ & $0.5886^{* * *}$ & $0.5909^{* * *}$ \\
\hline & (41.31) & $(41.40)$ & $(41.22)$ & (41.31) & (41.34) & $(41.20)$ & $(41.01)$ & (41.31) \\
\hline Observations & 5,507 & 5,507 & 5,507 & 5,507 & 5,507 & 5,507 & 5,507 & 5,507 \\
\hline $\begin{array}{l}\text { Log-likelihood } \\
\text { (LIK) }\end{array}$ & 2825.97 & 2830.23 & 2824.94 & 2824.67 & 2828.18 & 2824.94 & 2827.36 & 2824.65 \\
\hline
\end{tabular}

Sources: Rais (available at: <https://bit.ly/3bbz8Y2>; accessed on: Jan. 15, 2016); Ipeadata (available at: <https://bit. ly/3gL2UUw>; accessed on: Jan. 20, 2016); Atlas do Desenvolvimento Humano (available at: <https://bit.ly/3gETc6g>; accessed on: Jan. 25, 2016).

Authors' elaboration.

Obs.: 1. Numbers between brackets are $z$ statistics.

2. ${ }^{* *},{ }^{* *}$ and ${ }^{*}$ indicate that estimated parameters are significantly different from zero at $1 \%, 5 \%$ and $10 \%$ levels.

In the main variables under investigation, firm size, findings indicate a positive and statistically significant sign for the small manufacturing variable. Therefore, it can be inferred that in municipalities where the percentage of employees in small firms of the industrial sector was higher, the growth of per capita income was faster. This result is consistent with the results obtained by Shaffer (2002) in an analysis for US counties. 
For the other size of firms in manufacturing sector, the findings show not significant effect in income growth.

In the service sector, the relation between size firm and income growth is different. The medium firms have a positive relation with the income growth, while the micro ones have a negative relation with the growth of per capita income. The results are not significant for small and large enterprises in the service sector.

The different results related to micro and small firms in service and manufacturing sector are in consonance with Rajan and Zingales (2001), whose claim is that different mechanism and characteristics work in different sectors. This fact tends to possibly generate impact on the income that vary according to the sector analyzed.

In both service and manufacturing sector, the large business did not show statistical significance in relation the income growth.

The findings related to employment model (table 5) presented negative sign to the microenterprises. Therefore, it is not possible to infer the impact of the presence of small firms in the employment growth rate. This results are in opposition to the view that smaller firms are generally associated to larger rates of employment growth, probably due to the fact that in developing countries the role of micro and small enterprises is not clear due to not well established institutions (Deller and McConnon Junior, 2009).

\section{TABLE 5}

\begin{tabular}{|c|c|c|c|c|c|c|c|c|}
\hline \multirow{4}{*}{$\begin{array}{c}\text { Variables } \\
\text { Ln employment }\end{array}$} & \multicolumn{8}{|c|}{ Employment growth } \\
\hline & \multicolumn{4}{|c|}{ Manufacturing } & \multicolumn{4}{|c|}{ Service } \\
\hline & $-0.5529^{* * *}$ & $-0.5544^{* * *}$ & $-0.5567^{* * *}$ & $-0.5577^{* * *}$ & $-0.4256^{* * *}$ & $-0.5471^{* * *}$ & $-0.5534^{* * *}$ & $-0.4802^{* * *}$ \\
\hline & $(-62.85)$ & $(-62.46)$ & $(-62.58)$ & $(-62.97)$ & $(-46.51)$ & $(-57.24)$ & $(-62.87)$ & $(-49.27)$ \\
\hline \multirow{2}{*}{ Ln population } & $0.5553^{* * *}$ & $0.5565^{* * *}$ & $0.5551^{* * *}$ & $0.5538^{* \star *}$ & $0.4255^{* * *}$ & $0.5453^{* * *}$ & $0.5622^{* * *}$ & $0.5048^{* * *}$ \\
\hline & (43.36) & (43.49) & (43.39) & $(43.30)$ & $(33.87)$ & $(42.63)$ & (43.31) & (39.03) \\
\hline \multirow{2}{*}{ Education } & $0.0078^{* * *}$ & $0.0077^{* * *}$ & $0.0078^{* * *}$ & $0.0074^{* * *}$ & 0.0034 & $0.0070^{* * *}$ & $0.0076^{* * *}$ & $0.0053^{* *}$ \\
\hline & (3.27) & (3.26) & (3.30) & (3.13) & (1.58) & (2.96) & (3.22) & (2.30) \\
\hline \multirow{2}{*}{ Health } & $-0.0058^{* * *}$ & $-0.0055^{* * *}$ & $-0.0056^{* * *}$ & $-0.0058^{* * *}$ & $-0.0029^{* * *}$ & $-0.0053^{* * *}$ & $-0.0055^{* * *}$ & $-0.0035^{* * *}$ \\
\hline & $(-5.83)$ & $(-5.54)$ & $(-5.68)$ & $(-5.90)$ & $(-3.19)$ & $(-5.37)$ & $(-5.56)$ & $(-3.62)$ \\
\hline \multirow{2}{*}{$\begin{array}{l}\text { Population } \\
\text { density }\end{array}$} & $-0.00003^{*}$ & $-0.00003^{*}$ & $-0.00003^{*}$ & $-0.00003^{*}$ & -0.0000008 & -0.00003 & $-0.00003^{* *}$ & $-0.00003 *$ \\
\hline & $(-1.84)$ & $(-1.79)$ & $(-1.73)$ & $(-1.83)$ & $(-0.04)$ & $(-1.56)$ & $(-2.01)$ & $(-1.69)$ \\
\hline \multirow{2}{*}{ Physical capital } & $0.0556^{* * *}$ & $0.0571^{* * *}$ & $0.0554^{* * *}$ & $0.0554^{* * *}$ & $0.0270^{* * *}$ & $0.0546^{* * *}$ & $0.0578^{* * *}$ & $0.0411^{* * *}$ \\
\hline & (6.90) & (7.11) & (6.89) & $(6.91)$ & (3.69) & (6.85) & (7.19) & (5.20) \\
\hline \multirow{2}{*}{ Microfirms } & $-0.0377^{* *}$ & & & & $1.1063^{* * *}$ & & & \\
\hline & $(-1.97)$ & & & & (29.30) & & & \\
\hline \multirow{2}{*}{ Small firms } & & 0.0426 & & & & $0.3485^{* * *}$ & & \\
\hline & & $(1.50)$ & & & & (8.22) & & \\
\hline
\end{tabular}




\begin{tabular}{|c|c|c|c|c|c|c|c|c|}
\hline \multirow{2}{*}{ Variables } & \multicolumn{8}{|c|}{ Employment growth } \\
\hline & \multicolumn{4}{|c|}{ Manufacturing } & \multicolumn{4}{|c|}{ Service } \\
\hline \multirow{2}{*}{ Medium firms } & & & $0.1123^{* * *}$ & & & & $0.0731^{* *}$ & \\
\hline & & & (3.04) & & & & $(2.53)$ & \\
\hline \multirow{2}{*}{ Large firms } & & & & $0.2471^{* * *}$ & & & & $-0.3904^{* * *}$ \\
\hline & & & & $(4.48)$ & & & & $(-15.76)$ \\
\hline \multirow{2}{*}{$\lambda$} & $0.2958 * * *$ & $0.2974^{* * *}$ & $0.2951 * * *$ & $0.2964^{* * *}$ & $0.2452^{* * *}$ & $0.2952^{* * *}$ & $0.3001 * * *$ & $0.2936^{\star * *}$ \\
\hline & (15.29) & (15.39) & (15.25) & (15.33) & (12.27) & (15.25) & $(15.56)$ & (15.15) \\
\hline Observations & 5,507 & 5,507 & 5,507 & 5,507 & 5,507 & 5,507 & 5,507 & 5,507 \\
\hline $\begin{array}{l}\text { Log-likelihood } \\
\text { (LIK) }\end{array}$ & -4700.21 & -4701.03 & -4697.54 & -4692.11 & -4307.05 & -4668.51 & -4698.95 & -4580.62 \\
\hline
\end{tabular}

Sources: Rais (available at: <https://bit.ly/3bbz8Y2>; accessed on: Jan. 15, 2016); Ipeadata (available at: <https://bit. ly/3gL2UUw>; accessed on: Jan. 20, 2016); Atlas do Desenvolvimento Humano (available at: <https://bit.ly/3gETc6g>; accessed on: Jan. 25, 2016).

Authors' elaboration.

Obs.: 1. Numbers between brackets are $z$ statistics.

2. ${ }^{* *},{ }^{* *}$ and ${ }^{*}$ indicate that estimated parameters are significantly different from zero at $1 \%, 5 \%$ and $10 \%$ levels.

The positive sign to medium and large firms in the manufacturing sector indicates that in municipalities where the presence of medium and large enterprises of the industrial sector was higher, the growth of employment was faster.

The relation between firm size and employment growth is also different when is analyzed the service sector. The findings show a positive and significant sign to the variables micro, small and medium enterprises. By inserting the variable referring to large firms, the findings show a negative and significant sign for the large ones in the service sector. Such finding indicates that in the regions where the presence of large firms of the service sector is higher, the growth rate of employment is lower.

This difference between services and manufacturing, with opposite trends between sectors, it is even clearer than the difference found in the income model. In this model, the smaller the firm size in the service sector, higher employment growth. While in manufacturing larger firms are positively correlated with employment growth.

The negative sign of the natural logarithm of employment in the first year indicates a convergence process, as in income model. The variables related to population, education and physical capital presented a positive sign. This demonstrated the importance of such variables in order to explain the growth of employment. The variables related to health and agglomeration effects presented negative and significant sign.

In both models, income e employment, the spatial parameter for the spatially lagged error term $(\lambda)$ presented positive and significant values. It means that a random shock introduced in a specific municipality will impact, besides the income and employment rates of the same municipality, it will impact also the income and employment rates of others municipalities. 
The findings on firm size and poverty growth (table 6 ) indicate statistic significance only for firms in the manufacturing sector. The results show that different size of firm differ in terms of their impact on poverty growth.

Micro firms in the manufacturing sector have a positive and statistically significant relation with growth in poverty. Then it can be said that faster poverty growth is found in municipalities with more micro firm activity. On the other hand, municipalities with more small, medium and large firms in the manufacturing sector are related with lower poverty growth, specially the medium and large ones that presented higher coefficient associated to poverty growth.

TABLE 6

Results of spatial autoregressive model (SAR) - poverty growth

\begin{tabular}{|c|c|c|c|c|c|c|c|c|}
\hline \multirow{2}{*}{ Variables } & \multicolumn{8}{|c|}{ Poverty growth } \\
\hline & \multicolumn{4}{|c|}{ Manufacturing } & \multicolumn{4}{|c|}{ Service } \\
\hline \multirow{2}{*}{ Ln poverty } & $-0.1310^{* * *}$ & $-0.1310^{* * *}$ & $-0.1347^{* * *}$ & $-0.1295^{* * *}$ & $-0.1275^{* * *}$ & $-0.1301^{* * *}$ & $-0.1281^{* * *}$ & $-0.1265^{* * *}$ \\
\hline & $(-9.23)$ & $(-9.25)$ & $(-9.48)$ & $(-9.16)$ & $(-8.99)$ & $(-9.17)$ & $(-9.05)$ & $(-8.89)$ \\
\hline \multirow{2}{*}{ Ln population } & $0.0520^{* * *}$ & $0.0538^{* * *}$ & $0.0556^{* * *}$ & $0.0533^{* * *}$ & $0.0507^{* * *}$ & $0.0515^{* * *}$ & $0.0518^{* * *}$ & $0.0516^{* * *}$ \\
\hline & $(10.44)$ & $(10.75)$ & $(10.97)$ & $(10.57)$ & $(10.24)$ & $(10.37)$ & $(10.24)$ & (10.36) \\
\hline \multirow{2}{*}{ Education } & $-0.0028^{* *}$ & $-0.0028^{* *}$ & $-0.0028^{* *}$ & $-0.0026^{* *}$ & $-0.0027^{\star *}$ & $-0.0027^{\star *}$ & $-0.0027^{* *}$ & $-0.0027^{* *}$ \\
\hline & $(-2.47)$ & $(-2.49)$ & $(-2.45)$ & $(-2.31)$ & $(-2.41)$ & $(-2.36)$ & $(-2.38)$ & $(-2.38)$ \\
\hline \multirow{2}{*}{ Health } & $0.006^{* * *}$ & $0.0057^{* * *}$ & $0.0059^{* * *}$ & $0.006^{* * *}$ & $0.0059^{* * *}$ & $0.0059^{* * *}$ & $0.0059^{* * *}$ & $0.0059^{* * *}$ \\
\hline & $(11.57)$ & $(11.10)$ & $(11.50)$ & (11.54) & $(11.45)$ & $(11.43)$ & $(11.46)$ & (11.46) \\
\hline \multirow{2}{*}{$\begin{array}{l}\text { Population } \\
\text { density }\end{array}$} & $0.00003^{* * *}$ & $0.00003^{* * *}$ & $0.00003^{* * *}$ & $0.00003^{* * *}$ & $0.00003^{* * *}$ & $0.00003^{* * *}$ & $0.00003^{* * *}$ & $0.00003^{* * *}$ \\
\hline & (3.93) & $(3.70)$ & $(3.77)$ & $(3.90)$ & $(3.96)$ & (3.89) & $(3.84)$ & (3.88) \\
\hline \multirow{2}{*}{ Physical capital } & $-0.0584^{* * *}$ & $-0.0586^{* * *}$ & $-0.0581^{* * *}$ & $-0.0582^{* * *}$ & $-0.0585^{* * *}$ & $-0.059^{* * *}$ & $-0.0586^{* * *}$ & $-0.0583^{* * *}$ \\
\hline & $(-11.86)$ & $(-11.92)$ & $(-11.81)$ & $(-11.80)$ & $(-11.87)$ & $(-11.98)$ & $(-11.89)$ & $(-11.80)$ \\
\hline \multirow{2}{*}{ Microfirms } & $0.0193^{*}$ & & & & 0.0183 & & & \\
\hline & $(1.84)$ & & & & $(0.93)$ & & & \\
\hline \multirow{2}{*}{ Small firms } & & $-0.0572^{* * *}$ & & & & -0.0325 & & \\
\hline & & $(-3.70)$ & & & & $(-1.40)$ & & \\
\hline \multirow{2}{*}{ Medium firms } & & & $-0.0835^{* * *}$ & & & & 0.0135 & \\
\hline & & & $(-4.16)$ & & & & $(0.85)$ & \\
\hline \multirow{2}{*}{ Large firms } & & & & $-0.0703^{* *}$ & & & & -0.0143 \\
\hline & & & & $(-2.34)$ & & & & $(-1.21)$ \\
\hline \multirow{2}{*}{$\rho$} & $0.583^{* * *}$ & $0.580^{* * *}$ & $0.5814^{* * *}$ & $0.5819^{* * *}$ & $0.5819^{* * *}$ & $0.5824^{* * *}$ & $0.5822^{* * *}$ & $0.5817^{* * *}$ \\
\hline & $(42.78)$ & $(42.51)$ & $(42.64)$ & $(42.66)$ & $(42.66)$ & $(42.72)$ & $(42.71)$ & (42.63) \\
\hline Observations & 5,507 & 5,507 & 5,507 & 5,507 & 5,507 & 5,507 & 5,507 & 5,507 \\
\hline $\begin{array}{l}\text { Log-likelihood } \\
\text { (LIK) }\end{array}$ & -1564.32 & -1559.17 & -1557.35 & -1563.26 & -1565.58 & -1565.04 & -1565.66 & -1565.29 \\
\hline
\end{tabular}

Sources: Rais (available at: <https://bit.ly/3bbz8Y2>; accessed on: Jan. 15, 2016); Ipeadata (available at: <https://bit. ly/3gL2UUw>; accessed on: Jan. 20, 2016); Atlas do Desenvolvimento Humano (available at: <https://bit.ly/3gETc6g>; accessed on: Jan. 25, 2016).

Authors' elaboration.

Obs.: 1. Numbers between brackets are $z$ statistics.

2. ${ }^{* * *},{ }^{* *}$ and ${ }^{*}$ indicate that estimated parameters are significantly different from zero at $1 \%, 5 \%$ and $10 \%$ levels. 
These results are in part according to the literature (Deller and McConnon Junior, 2009; Gebremariam, Gebremedhin and Jackson, 2004) that defends the importance of small and medium enterprises (SME) for poverty reduction. However also brings results regarding the importance of large firms for the poverty alleviation. The negative relation between poverty growth and large firms can be explained by the more permanent and effective jobs associated to large firms (Shaffer, 2006b).

As in income and employment models, the natural logarithm of poverty in the first year presented a negative sign, indicating a convergence process. The education and physical capital also presented negative sign. The variables related to health, agglomeration and population show positive and significant sign.

The positive and significant value of the spatial parameter $\rho$ indicates that municipalities whose neighbors have high growth of poverty tend to have higher poverty growth as well.

\section{DISCUSSION AND CONCLUSION}

The purpose of this work is to analyze in an empirical manner the relation between firm size and economic development of Brazilian municipalities during the period from 2000 to 2010. More specifically, we used spatial econometrics to analyze the relation between size of manufacturing/service firms and the growth rate of income, employment and poverty.

The use of the municipalities-level data, the different economic development metrics and the sector-specific data used here are more disaggregated than in most prior studies. It allows us to better understanding the issue.

The findings indicate that firm size plays an important role on economic development. Nonetheless the results change according to the metric of measure and the type of sector. This dissimilarity can be associated to different mechanisms and characteristics that are related to different sectors.

The estimated models allow us to obtain some important results. Considering manufacturing sectors, employment growth is significantly and positively related to the size of the firm, whereas the same relation is statistically significant and negative for service sectors. Consistently with this, when poverty growth becomes the exogenous variable, the size of manufacturing firms has the opposite sign: small, medium, and large ones present significant and negative effect on poverty growth. Finally and quite unexpectedly, microenterprises of service sectors have negative effect on income growth, contrasting to their positive effect on employment. 
Overall, the results have some implications to policy makers. The main one point is regarding the dissimilarity findings across sectors and development indicators. This fact recommends special attention on the part of policy makers in formulating their local development strategies. Thus, one should take into account specific regional needs to establish appropriated environment and policies.

\section{REFERENCES}

ACS, Z.; DESAI, S.; HESSELS, J. Entrepreneurship, economic development and institutions. Small Business Economics, n. 31, p. 219-234, Oct. 2008.

AMORÓS, J. E.; CRISTI, O. Poverty and entrepreneurship in developing countries. In: MINNITI, M. (Ed.). The Dynamics of entrepreneurship: evidence from global entrepreneurship monitor data. Oxford: Oxford University Press, 2011. p. 209-230.

ANSELIN, L. The moran scatterplot as an ESDA tool to assess local instability in spatial association. In: FISCHER, M.; SCHOLTEN, H.; UNWIN, D. (Eds.). Spatial analytical perspectives on GIS. London: Taylor and Francis, 1996. p. 111-125.

. Under the hood: issues in the specification and interpretation of spatial regression models. Agricultural Economics, Milwaukee, v. 27, n. 3, p. 247-267, Nov. 2002.

AYYAGARI, M.; DEMIRGUC-KUNT, A.; MAKSIMOVIC, V. Who creates jobs in developing countries? Small Business Economics, v. 43, n. 1, p. 75-99, 2014.

BADINGER, H.; MÜLLER, W.; TONDL, G. Regional convergence in the European Union, 1985-1999: a spatial dynamic panel analysis. Regional Studies, Sussex, v. 38, n. 3, p. 241-253, 2004.

BANERJEE, A. V.; DUFLO, E. The Economic lives of the poor. Journal of Economic Perspectives, v. 21, n. 1, p. 141-167, 2007.

BARROS NETO, G.; NAKABASHI, L.; SAMPAIO, A. Determinantes do capital físico: o papel do capital humano e da qualidade institucional. In: ENCONTRO NACIONAL DE ECONOMIA, 41st., 2013, Foz do Iguaçú. Anais... Foz do Iguaçú: Anpec, 2013.

BECK, T.; DEMIRGUC-KUNT, A.; LEVINE, R. SMEs, growth, and poverty: cross-country evidence. Journal of Economic Growth, n. 10, p. 199-229, Sept. 2005.

BRUCE, D. et al. (Small) business activity and state economic growth: does size matter? Regional Studies, Sussex, v. 43, n. 2, p. 229-245, Apr. 2009. 
CHEN, J.; GUO, F.; ZHU, A. The housing-led growth hypothesis revisited: evidence from the Chinese provincial panel data. Urban Studies, Glasgow, v. 48, n. 10, p. 2049-2067, Aug. 2011.

CRAVO, T. A.; BECKER, B.; GOURLAY, A. SMEs and regional economic growth in Brazil. Small Business Economics, v. 38, n. 2, p. 217-230, Feb. 2012.

Regional growth and SMEs in Brazil: a spatial panel approach. Regional Studies, Sussex, v. 49, n. 12, p. 1-22, May 2015.

DALL'ERBA, S.; LE GALLO, J. Regional convergence and the impact of European structural funds over 1989-1999: a spatial econometric analysis. Papers in Regional Science, Azores, v. 87, n. 2, p. 219-245, 2008.

DE DOMINICIS, L; ARBIA, G; DE GROOT, H, L. Concentration of manufacturing and service sector in Italy: accounting for spatial dependence and firm size distribution. Regional Studies, Sussex, v. 47, n. 3, p. 405-418, 2013.

DELLER, S. C. Spatial variations in the role of microenterprises in economic growth. The Review of Regional Studies, v. 40, n. 1, p. 71-97, 2010.

DELLER, S. C.; MCCONNON JUNIOR, J. C. Microenterprises and economic growth: a panel study of the US states 1977-1997. Applied Economic Letters, v. 16, n. 13, p. 1307-1312, 2009.

ERTUR, C.; KOCH, W. Growth, technological interdependence and spatial externalities: theory and evidence. Journal of Applied Econometrics, v. 22, n. 6, p. 1033-1062, Sept./Oct. 2007.

GEBREMARIAM, G.; GEBREMEDHIN, T.; JACKSON, R. The role of small business in economic growth and poverty alleviation in West Virginia: an empirical analysis. In: AMERICAN AGRICULTURAL ECONOMICS ASSOCIATION ANNUAL MEETING, 2004, Denver. Anais... Denver, Colorado: AAEA, Aug. 2004.

KOMAREK, T.; LOVERIDGE, S. Firms size and economic development: estimating long-term effects on U.S. county growth, 1990-2000. Journal of Regional Science, v. 55, n. 2, p. 262-279, Mar. 2015.

LIMA, R. C.; SILVEIRA NETO, R. M. Physical and human capital and Brazilian regional growth: spatial econometric approach for the period 1970-2010. Regional Studies, Sussex, v. 50, n. 10, p. 1688-1701, 2016.MCDONALD, S.; ROBERTS, J. Growth and multiple forms of human capital in an augmented Solow model: a panel data investigation. Economics Letters, v. 74, n. 2, p. 271-276, Jan. 2002.

MOHL, P.; HAGEN, T. Do EU structural funds promote regional growth? New evidence from various panel data approaches. Regional Science and Urban Economics, n. 40, n. 5, p. 353-365, Sep. 2010. 
MOSCARINI, G.; POSTEL-VINAY, F. The Contribution of large and small employers to job creation in times of high and low unemployment. American Economic Review, v. 102, n. 6, p. 2509-2539, 2012.

NAKABASHI, L.; PEREIRA, A.; SACHSIDA, A. Institutions and growth: a developing country case study. Journal of Economic Studies, v. 40, n. 5, p. 614634, 2013.

NEUMARK, D.; WALL, B.; ZHANG, J. Do small businesses create more jobs? New evidence for the United States from the national establishment time series. The Review of Economics and Statistics, v. 93, n. 1, p. 16-29, 2011.

RAJAN, R. G.; ZINGALES, L. The Firm as a dedicated hierarchy: a theory of the origins and growth of firms. The Quarterly Journal of Economics, v. 116, n. 3, p. 805-851, 2011.

RUPASINGHA, A.; GOETZ, S. J. Self-employment and local economic performance: evidence from US counties. Papers in Regional Science, v. 92, n. 1, p. 141-162, 2013.

SHAFFER, S. Firm size and economic growth. Economic Letters, v. 76, n. 2, p. 195-203, July 2002.

. Establishment size and local employment growth. Small Business Economics, n. 26, n. 5, p. 439-454, June 2006 a.

. Establishment size by sector and county-level economic growth. Small Business Economics, v. 26, n. 2, p. 145-154, Mar. 2006 b.

VAN STEL, A.; CARREE, M.; THURIK, R. The effect of entrepreneurial activity on national economic growth. Small Business Economics, n. 24, p. 311-321, Apr. 2005.

\section{COMPLEMENTARY BIBLIOGRAPHY}

ANSELIN, L. Spatial econometrics: methods and models. Dordrecht, Netherlands: Springer, 1988.

. Local indicators of spatial association - LISA. Geographical Analysis, Ohio, v. 27, n. 2, p. 93-115, Apr. 1995.

ARAÚJO, G. D.; HIRATUKA, C. Exportações das firmas domésticas e influências das firmas transnacionais. In: DE NEGRI, J. A.; ARAÚJO, B. C. (Eds.). As empresas brasileiras e o comércio internacional. Brasilia: Ipea, 2007. p. 317-339. ARBIA, G.; LE GALLO, J.; PIRAS, G. Does evidence on regional convergence depend on the estimation strategy? Outcomes from analysis of a set of NUTS2 EU regions. Spatial Economic Analysis, Sussex, v. 3, n. 2, p. 209-224, June 2008. 
BIESEBROECK, J. V. Firm size matters: growth and productivity growth in African manufacturing. Economic Development and Cultural Change, Chicago, v. 53, n. 3, p. 545-583, Apr. 2005.

CRAVO, T. A. SMEs and economic growth in the Brazilian micro-regions. Papers in Regional Science, Azores, v. 89, n. 4, p. 711-735, Nov. 2010.

DE NEGRI, J. A. Rendimentos crescentes de escala e o desempenho exportador das firmas no Brasil. In: DE NEGRI, J. A.; ARAÚJO, B. C. O. (Eds.). As empresas brasileiras e o comércio internacional. Brasilia: Ipea, 2007. p. 189-214.

DURLAUF, S. N.; JOHNSON, P. A.; TEMPLE, J. R. Growth econometrics. In: AGHION, P.; DURLAUF, S. (Eds.). Handbook of economic growth. [s.l.]: Elsevier, 2005. p. 555-677.

ERTUR, C.; LE GALLO, J.; BAUMONT, C. The European regional convergence process, 1980-1995: do spatial regimes and spatial dependence matters? International Regional Science Review, v. 29, n. 1, p. 3-34, Jan. 2006.

ESTEVE-PEREZ, S. et al. A survival analysis of manufacturing firms in export markets. In: ARAUZO-CAROD, J. M.; MANJON-ANTOLIN, M. C. Entrepreneurship, industrial location, and economic growth. Bloomington: Edward Elgar Publishing, 2007.

GOMES, V.; ELLERY JUNIOR, R. Perfil das exportaçóes, produtividade e tamanho das firmas no Brasil. Revista Brasileira de Economia, Rio de Janeiro, v. 61, n. 1, p. 33-48, Jan./Mar. 2007.

IDSON, T. L.; OI, W. Y. Workers are more productive in large firms. The American Economic Review, Pittsburgh, v. 89, n. 2, p. 104-108, May 1999.

LEE, K. et al. Big businesses and economic growth: identifying a binding constraint for growth with country panel analysis. Journal of Comparative Economics, v. 41, n. 2, p. 561-582, May 2013.

LESAGE, J. P.; PACE, R. K. Introduction to spatial econometrics. London: CRC Press/Taylor \& Francis Group, 2009.

LING-YEE, L.; OGUNMOKUN, O. The influence of interfirm relational capabilities on export advantage and performance: an empirical analysis. International Business Review, v. 10, n. 4, p. 399-420, Aug. 2001.

LIU, X.; SHU, C. Determinants of exports performance: evidence from Chinese industries. Economics of Planning, v. 36, n. 1, p. 45-67, Mar. 2003.

LOVERIDGE, S.; NIZALOV, D. Operationalizing the entrepreneurial pipeline theory: an empirical assessment of the optimal size distribution of local firms. Economic Development Quarterly, Cleveland, v. 21, n. 3, p. 244-262, Aug. 2007. 
MUELLER, P. Exploiting entrepreneurial opportunities: the impact of entrepreneurship on growth. Small Business Economics, v. 28, n. 4, p. 355-362, Apr. 2007. PAGANO, P.; SCHIVARDI, F. Firm size distribution and growth. The Scandinavian Journal of Economics, v. 105, n. 2, p. 255-274, June 2003.

RAMAJO, J. et al. Spatial heterogeneity and interregional spillovers in the European Union: do cohesion policies encourage convergence across regions? European Economic Review, v. 52, n. 3, p. 551-567, Apr. 2008.

RESENDE, G. Multiple dimensions of regional economic growth: the Brazilian case, 1991-2000. Papers in Regional Science, Azores, v. 90, n. 3, p. 629-662, Aug. 2011.

REY, S. J.; MONTOURI, B. D. US regional income convergence: a spatial econometric perspective. Regional Studies, Sussex, v. 33, n. 2, p. 143-156, 1999.

SILVA, C. E. L. O impacto do BNDES Exim no tempo de permanência das firmas brasileiras no mercado internacional: uma análise a partir dos microdados. Planejamento e Políticas Públicas, Brasília, n. 38, p. 9-36, Jan./June 2012.

SILVEIRA-NETO, R.; AZZONI, C, R. Location and regional income disparity dynamics: the Brazilian case. Papers in Regional Science, Azores, v. 85, n. 4, p. 599-613, Feb. 2006.

ZWEIFEL, P. Services in Switzerland: structure, performance, and implications of European economic integration. Berlin; Hidelberg: Springer-Verlag, 1993. 
RESULTS OF MORAN'S I

The table A. 1 shows the results of Moran's I for all variables used in the regressions with different weights matrices.

\begin{tabular}{|c|c|c|c|c|c|c|c|c|}
\hline & $\begin{array}{l}\text { Income } \\
\text { growth }\end{array}$ & $\begin{array}{l}\text { Employment } \\
\text { growth }\end{array}$ & In income & $\begin{array}{c}\text { In } \\
\text { employment }\end{array}$ & $\begin{array}{l}\text { Human } \\
\text { capital }\end{array}$ & $\begin{array}{c}\text { Population } \\
\text { density }\end{array}$ & \multicolumn{2}{|c|}{ Child mortality } \\
\hline \multirow{2}{*}{ Queen first } & 0.3042 & 0.2488 & 0.7908 & 0.3971 & 0.4638 & 0.5009 & \multicolumn{2}{|c|}{0.8431} \\
\hline & $(0.001)$ & $(0.001)$ & $(0.001)$ & $(0.001)$ & $(0.001)$ & $(0.001)$ & \multicolumn{2}{|c|}{$(0.001)$} \\
\hline \multirow{2}{*}{ Queen second } & 0.2808 & 0.2362 & 0.7686 & 0.3581 & 0.4139 & 0.3323 & \multicolumn{2}{|c|}{0.8294} \\
\hline & $(0.001)$ & $(0.001)$ & $(0.001)$ & $(0.001)$ & $(0.001)$ & $(0.001)$ & \multicolumn{2}{|c|}{$(0.001)$} \\
\hline \multirow{2}{*}{ Queen third } & 0.2602 & 0.2272 & 0.7472 & 0.3252 & 0.3797 & 0.2217 & \multicolumn{2}{|c|}{0.8103} \\
\hline & $(0.001)$ & $(0.001)$ & $(0.001)$ & $(0.001)$ & $(0.001)$ & $(0.001)$ & \multicolumn{2}{|c|}{$(0.001)$} \\
\hline \multirow{2}{*}{ k-nearest $(k=5)$} & 0.31 & 0.2491 & 0.7914 & 0.4023 & 0.4606 & 0.5785 & \multicolumn{2}{|c|}{0.8526} \\
\hline & $(0.001)$ & $(0.001)$ & $(0.001)$ & $(0.001)$ & $(0.001)$ & $(0.001)$ & \multicolumn{2}{|c|}{$(0.001)$} \\
\hline \multirow{2}{*}{$k$-nearest $(k=10)$} & 0.2953 & 0.2437 & 0.7825 & 0.3871 & 0.4347 & 0.4545 & \multicolumn{2}{|c|}{0.8436} \\
\hline & $(0.001)$ & $(0.001)$ & $(0.001)$ & $(0.001)$ & $(0.001)$ & $(0.001)$ & \multicolumn{2}{|c|}{$(0.001)$} \\
\hline \multirow{4}{*}{ k-nearest $(k=15)$} & 0.2866 & 0.2429 & 0.7760 & 0.3744 & 0.4205 & 0.3981 & \multicolumn{2}{|c|}{0.8371} \\
\hline & $(0.001)$ & $(0.001)$ & $(0.001)$ & $(0.001)$ & $(0.001)$ & $(0.001)$ & \multicolumn{2}{|c|}{$(0.001)$} \\
\hline & \multicolumn{4}{|c|}{ Manufacturing } & \multicolumn{4}{|c|}{ Service } \\
\hline & Micro & Small & Medium & Large & Micro & Small & Medium & Large \\
\hline \multirow{2}{*}{ Queen first } & 0.0831 & 0.1145 & 0.1516 & 0.1131 & 0.1063 & 0.0802 & 0.0802 & 0.2111 \\
\hline & $(0.001)$ & $(0.001)$ & $(0.001)$ & $(0.001)$ & $(0.001)$ & $(0.001)$ & $(0.001)$ & $(0.001)$ \\
\hline \multirow{2}{*}{ Queen second } & 0.0723 & 0.1035 & 0.1251 & 0.0929 & 0.0886 & 0.0658 & 0.0831 & 0.2059 \\
\hline & $(0.001)$ & $(0.001)$ & $(0.001)$ & $(0.001)$ & $(0.001)$ & $(0.001)$ & $(0.001)$ & $(0.001)$ \\
\hline \multirow{2}{*}{ Queen third } & 0.0583 & 0.0924 & 0.1143 & 0.0756 & 0.0849 & 0.0571 & 0.0791 & 0.1986 \\
\hline & $(0.001)$ & $(0.001)$ & $(0.001)$ & $(0.001)$ & $(0.001)$ & $(0.001)$ & $(0.001)$ & $(0.001)$ \\
\hline \multirow{2}{*}{ k-nearest $(k=5)$} & 0.0978 & 0.1271 & 0.1490 & 0.1105 & 0.1151 & 0.0901 & 0.0997 & 0.2353 \\
\hline & $(0.001)$ & $(0.001)$ & $(0.001)$ & $(0.001)$ & $(0.001)$ & $(0.001)$ & $(0.001)$ & $(0.001)$ \\
\hline \multirow{2}{*}{$k$-nearest $(k=10)$} & 0.0860 & 0.1179 & 0.1400 & 0.0940 & 0.0939 & 0.0684 & 0.0908 & 0.2256 \\
\hline & $(0.001)$ & $(0.001)$ & $(0.001)$ & $(0.001)$ & $(0.001)$ & $(0.001)$ & $(0.001)$ & $(0.001)$ \\
\hline \multirow{2}{*}{ k-nearest $(k=15)$} & 0.0782 & 0.1135 & 0.1350 & 0.0973 & 0.0947 & 0.0688 & 0.0928 & 0.2238 \\
\hline & $(0.001)$ & $(0.001)$ & $(0.001)$ & $(0.001)$ & $(0.001)$ & $(0.001)$ & $(0.001)$ & $(0.001)$ \\
\hline
\end{tabular}

Sources: Rais (available at: <https://bit.ly/3bbz8Y2>; accessed on: Jan. 15, 2016); Ipeadata (available at: <https://bit. ly/3gL2UUw>; accessed on: Jan. 20, 2016); Atlas do Desenvolvimento Humano (available at: <https://bit.ly/3gETc6g>; accessed on: Jan. 25, 2016).

Obs.: Numbers between brackets are $p$ values and indicate significance at $5 \%$.

Data de submissão: 30/10/2017

Primeira decisão editorial em: 27/9/2018

Aprovação final em: 27/9/2018 